\title{
PERBEDAAN MINAT WIRAUSAHA BERDASARKAN MEDIA PEMBELAJARAN SELAMA PEMBELAJARAN JARAK JAUH DI MASA PANDEMI
}

\author{
Siti Marti'ah ${ }^{1}$, Berta Dian Theodora ${ }^{2}$ \\ Universitas Indraprasta PGRI Jakarta \\ ${ }^{1}$ sitimartiah1@gmail.com, ${ }^{2}$ berta.dtos@gmail.com
}

\section{DOI}

https://doi.org/10.26740/jupe.v9n2.p4853

\author{
Article history \\ Received \\ 26 January 2021 \\ Revised \\ 20 February 2021 \\ Accepted \\ 23 February 2021
}

\section{How to cite}

Marti'ah, S., \& Theodora, B. D. (2021). Perbedaan Minat Wirausaha Berdasarkan Media Pembelajaran Selama Pembelajaran Jarak Jauh di Masa Pandemi. Jurnal Pendidikan Ekonomi (JUPE), 9(2), 48-53. https://doi.org/10.26740/jupe.v9n2.p4853

Kata Kunci: Minat Berwirausaha, Media Pembelajaran, Pembelajaran Jarak Jauh Keywords: entrepreneurial interest, learning media, distance learning

\section{Corresponding author \\ Berta Dian Theodora, \\ berta.dtos@gmail.com}

\begin{abstract}
Abstrak
Ketika proses belajar mengajar secara mendadak berganti dari klasikal ke pembelajaran jarak jauh (PJJ) perlu dilakukan penyesuaian metode dan media dengan bahan pelajaran. Pembelajaran jarak jauh memiliki keterbatasan alat dan media pembelajaran yang dapat dipakai, media yang dapat dipakai antara lain aplikasi pesan instan, rekaman video dan video conference. Matakuliah Kewirausahaan diajarkan menggunakan video dan pesan instan diharapkan mencapai tujuan pembelajar menjadikan mahasiswa memiliki minat menjadi seorang wirausaha setelah lulus. Penggunaan media pembelajaran selama PJJ perlu dilihat tingkat pengaruhnya terhadap tujuan pembelajaran oleh karenanya perlu dilihat apakah terdapat perbedaan tingkat minat berwirausaha mahasiswa berdasarkan media video dan pesan instan. Mahasiswa yang menerima perkuliahan kewirausahan sebanyak 128 orang menjadi sampel penelitian dan metode t-test dipakai untuk mengetahui adakah perbedaan diantara dua media tersebut. Hasil uji menunjukan bahwa tingkat minat berwirausaha mahasiswa berada pada kategori rendah dan terlihat tidak ada perbedaan pengaruh penggunaan media video dan pesan instan terhadap minat berwirausaha mahasiswa.
\end{abstract}

Abstract
When the teaching and learning process suddenly changes from classical to
distance learning (PJJ), it is necessary to adjust the methods and media with the
learning materials. Distance learning has limited learning tools and media that
can be used, such as instant messaging applications, video recording and video
conferencing. Entrepreneurship courses are taught using video and instant
messages and are expected to achieve learner goals, making students have an
interest in becoming an entrepreneur after graduation. The use of learning media
during PJJ needs to be seen on the level of its influence on learning objectives,
therefore it is necessary to see whether there are differences in the level of student
entrepreneurial interest based on video and instant messages. There were 128
students who received entrepreneurship courses as the research sample and the
t-test method was used to determine whether there was a difference between the
two media. The test results show that the level of student interest in
entrepreneurship is in the low category and there is no difference in the effect of
the use of video and instant messages on student interest in entrepreneurship.




\section{PENDAHULUAN}

Kondisi pandemi yang dialami bangsa Indonesia sejak bulan maret 2020 menyebabkan beberapa sektor mengalami penyesuaian dalam kegiatan sehari-hari. Salah satu sektor yang mengalami perubahan besar dalam kegiatannya adalah sektor pendidikan. Terjadinya pandemi menyebabkan kegiatan belajar mengajar secara tatap muka terganggu, akses fisik dari dan ke lingkungan sekolah ditutup demi melindungi keselamatan jiwa peserta didik dan pendidik. Kondisi ini menyebabkan proses pembelajaran dilakukan secara jarak jauh atau dikenal dengan pendidikan jarak jauh.

Pada tanggal 15 Juni 2020, menteri pendidikan dan kebudayaan mengumumkan tentang panduan penyelenggaraan pembelajaran pada tahun ajaran dan tahun akademik selama masa pandemi. Lokasi satuan pendidikan mengikuti ketentuan zona berdasarkan kondisi pandemi yaitu zona hijau, kuning, orange dan merah. Satuan pendidikan pada zona hijau dalam melakukan tatap muka setelah mendapatkan izin dari pemerintah daerah, sedangkan satuan pendidikan yang berada di daerah zona kuning, oranye dan merah dilarang melakukan proses pembelajaran tatap muka disatuan pendidikan dan tetap melanjutkan kegiatan belajar dari rumah.

Ketika proses belajar mengajar berganti dari tatap muka ke pembelajaran jarak jauh, pendidik perlu memikirkan penyesuaian antara metode dan media yang digunakan dengan materi yang disampaikan. Faktor yang menjadi pertimbangan antara lain ketersediaan sumber daya (manusia dan teknologi) dipihak pendidik maupun peserta didik. Pemilihan sumber daya, peralatan dan aktifitas yang sesuai perlu dilakukan kepada peserta didik agar pemahaman mengenai materi tetap maksimal ditengah kondisi pandemi berlangsung.

Pembelajaran kewirausahaan pada dilakukan dengan cara tatap muka, pelaksanaan proyek-proyek dan berbasis produksi akan menumbuhkan minat wirausaha mahasiswa (Farida.2017 dan Hidayat.2018) namun pembelajaran kewirausahaan pada ketika masa pandemi tidak bisa dilakukan dengan tatap muka atau proyek karena terkendala pembatasan sosial.

Pelaksanaan pembelajaran kewirausahaan pada semester gasal 2020/2021 di program studi informatika dilakukan secara online dan diketahui bahwa para pengajar dan mahasiswa belum terbiasanya menggunakan media pembelajaran daring dalam pembelajaran kewirausahaan. Perubahan media pembelajaran yang terjadi secara mendadak dikhawatirkan akan menyebahkan rendahnya minat mahasiswa untuk menjadi wirausaha.

Pengajar perlu mencari tahu media pembelajaran yang tepat untuk karakteristik dan materi pada matakuliah kewirausahaan sehingga dengan keterbatasan yang terjadi pembelajaran ini akan mencapai tujuannya yaitu menumbuhkan dan meningkatkan minat mahasiswa untuk berwirausaha.

Penelitian dilakukan agar pengajar dapat mengetahui tingkat minat berwirausaha mahasiswa setelah dilaukan pembelajaran jarak jauh (PJJ) secara daring dan apakah terdapat perbedaan minat berwirausaha berdasarkan media pembelajaran yang dipakai yaitu video dan pesan instan (WAG).

Pendidikan Jarak jauh (PJJ) bukanlah hal yang baru bagi dunia pendidikan di Indonesia sejak tahun 1950an (gambar 1) PJJ dilakukan melalui siaran radio untuk memberikan pendidikan bagi masyarakat dengan keterbatasan geografis. Selain siaran radio penggunaan media cetak dilakukan dengan cara dikirim ke siswa yang mengikuti pembelajaran/pelatihan. PJJ berkembang sejalan dengan perkembangan teknologi, adanya jaringan internet membuat pembelajaran dikenal dengan sistem elearning/pembelajaran online. Pengalaman puluhan tahun dalam melaksanakan pembelajaran jarak jauh di Indonesia masih belum dapat mempersiapkan para pendidik saat mengalami perubahan mendadak, terjadinya "syok" akibat perubahan dari pembelajaran tatap muka menjadi pembelajaran jarak jauh selama masa pandemic menjadi suatu kendala yang perlu dicari penyesuaiannya.

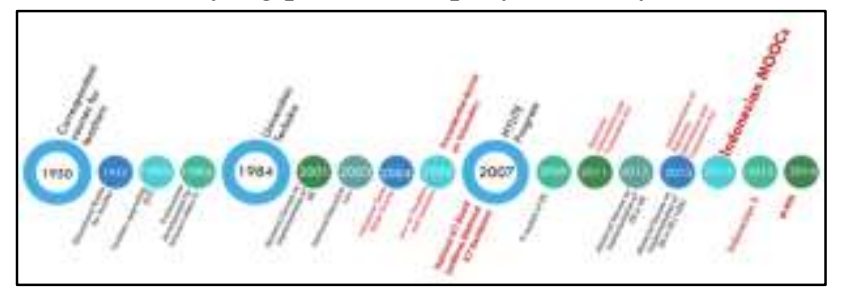

Gambar 1. Perlaksanaan Pembelajaran Jarak Jauh di Indonesia

Kegiatan pembelajaran jarak jauh selama masa pandemi telah dimulai pada semester genap tahun ajaran 2019-2020 dan beberapa hambatan yang ditemui selama berlangsungnya pembelajaran jarak jauh antara lain:

1. Keterbatasan kemampuan pendidik dalam mengoperasikan aplikasi pembelajaran dan perangkat digital

2. Peserta didik memiliki sarana dan prasarana yang terbatas seperti kuota data

3. Penggunaan dan ketersediaan waktu pendidik menjadi terbatas, dikarenakan pendidik berada dilingkungan keluarga bukan berada dilingkungan belajar.

4. Pendidik tidak dapat mengamati secara langsung perkembangan pemahaman peserta didik

Pembelajaran jarak jauh memiliki keterbatasan lainnya yaitu kepemilikan alat dan pengetahuan mengenai cara 
operasionalnya, beberapa media pembelajaran daring yang dipakai oleh pendidik yaitu power point, rekaman video dan video conference.

Media Pembelajaran yang digunakan oleh pendidik salah satunya dikenal dengan multimedia yaitu pengintegrasian lebih dari satu media dalam berkomunikasi atau penggabungan berbagai media seperti teks, suara, grafik, animasi, video, gambar, dan model spasial dalam sistem computer sedangkan media pembelajaran interaktif adalah sistem komunikasi efektif berbasis komputer yang menciptakan, menyimpan, menyajikan, dan mengakses kembali informasi berupa teks, grafik, suara, video atau animasi (Gayestik dalam Soenarto, 2009). Vural dan Zellner (dalam Turkoguz, 2012) menambahkan bahwa pembelajaran dengan perangkat media visual memberikan beberapa manfaat antara lain kejujuran emosional invididu, komunikasi yang efektif dan fleksibilitas dalam aktivitas belajar.

Penggunaan beberapa media tersebut mengalami kendala, Firman dan Rahman (2020) menyimpulkan batasan yang dialami mahasiswa dan dosen selama pelaksanaan pembelajaran online yaitu 1) dosen tidak dapat memantau secara langsung aktivitas mahasiswa selama perkuliahan, 2) mahasiswa mengalami kesulitan memahami bahan ajar yang disampaikan secara online dan 3) komunikasi yang terbatas melalui aplikasi pesan dan kelas virtual dirasa kurang cukup oleh mahasiswa. Firman dan Rahman menuliskan beberapa hal yang perlu diperhatikan selama pelaksanaan pembelajaran secara online yaitu ketersediaan layanan internet dan biaya tambahan yang dikeluarkan oleh mahasiswa. Layanan internet yang bergantung pada cuaca sehingga mempengaruhi sinyal serta kuota data yang dimiliki.

Kondisi pembelajaran yang mengalami perubahan secara mendadak menjadi perhatian pendidik ditengah pemberlakuan pembelajaran jarak jauh khususnya selama masa pandemi. Penggunaan teknologi mobile dalam mencapai tujuan pembelajaran jarak jauh memiliki kontribusi besar dan selama pelaksanaannya membutuhkan dukungan perangkat-perangkat mobile seperti telepon pintar, tablet dan laptop yang dapat mengakses informasi dimana saja dan kapan saja serta terhubung dengan internet (Korucu \& Alkan, 2011; Gikas \& Grant, 2013). Berbagai media dalam bentuk aplikasi dapat pula digunakan guna mendukung pelaksanaan pembelajaran jarak jauh, antara lain kelas virtual menggunakan layanan Google Classroom dan applikasi pesan instan seperti WhatsApp (So, 2016; Iftakhar, 2016).

Al Idrus (2017) memberikan beberapa variabel yang penting untuk diperhatikan oleh pendidik ketika melakukan proses belajar mengajar terutama dalam pembelajaran kewirausahaan, variabel tersebut antara lain tujuan dan karakteristik materi, kendala dalam proses penyampaian serta karakteristik pembelajar.

Minat Berwirausaha.

Minat adalah suatu sikap yang berlangsung secara terus menerus yang mempolakan perhatian seseorang, sehingga membuat dirinya menjadi selektif terhadap objek yang diminati, serta perasaan yang menyatakan bahwa suatu aktivitas, pekerjaan atau objek itu berharga atau berarti bagi individu (Kamus Psikologi.2002).

Minat berwirausaha merupakan suatu ketertarikan dan keinginan untuk terlibat dalam kegiatan kewirausahaan. Minat berwirausaha muncul dari beberapa faktor yang mempengaruhi seseorang antara lain pendidikan, pengalaman, dukungan akademik, dukungan sosial dan dukungan lingkungan usaha merupakan faktor kontekstual yang berpengaruh terhadap minat berwirausaha (Suharti \& Sirine.2011).

Suryana (2013) mengungkapkan bahwa, "berwirausaha adalah kegiatan usaha yang mengandalkan kemampuan kreatif dan inovatif yang dijadikan dasar, kiat dan sumber daya untuk mencari peluang menuju sukses". Sifat-sifat yang umum dimiliki seorang wirausaha yaitu 1) Motivasi berprestasi tinggi, 2) Selalu menatap masa depan dengan optimis, 3) Kreativitas tinggi, 4) Komitmen dalam pekerjaan, 5) Mandiri atau tidak ketergantungan, 6) berani mengambil resiko, 7) Selalu mencari peluang, 8) Memiliki jiwa kepemimpinan, 9) Memiliki kemampuan manajerial dan 10) Memiliki keterampilan personal.

Zimmerer dan Scarborough (1998) menjelaskan bahwa terdapat beberapa hal yang mempengaruhi minat seseorang untuk berwirausaha yaitu motivasi dari dalam diri dan orang lain serta pendidikan yang diterima dan Alma (2013) menyebutkan tiga faktor yang mempengaruhi seseorang untuk berwirausaha yaitu 1) faktor Personal, 2) faktor Environment dan 3) faktor Sociological.

Seorang wirausahawan memiliki sifat-sifat yang dapat diajarkan dan dipengaruhi pula oleh lingkungannya, oleh karenanya dalam perkuliahan kewirausahaan ditetapkan tujuan-tujuan pembelajaran yang akan menanamkan sifat tersebut. Tujuan pembelajaran Kewirausahaan antara lain 1)Meretas jiwa wirausaha melalui pendidikan tinggi, 2)Konsep dasar kewirausahaan, 3)Potensi wirausaha, 4)Motivasi dan kepemimpinan dalam kewirausahaan, 5)Kreativitas dan inovasi dalam kewirausahaan serta 6)Manajemen dalam wirausaha.

\section{METODE}

Pembelajaran Jarak Jauh yang dimaksud dalam penelitian ini adalah pembelajaran yang menggunakan media pembelajaran video yang dikirimkan dan aplikasi pesan, kedua media tersebut menggunakan layanan internet untuk penyampaiannya. 
Penelitian dilakukan dengan pendekatan kuantitatif Independent t-test dengan variabel penelitian adalah media pembelajaran dan minat berwirausahaha. Uji Independent t-test dilakukan guna mengetahui apakah terdapat perbedaan antar dua media yang dipakai oleh dosen dalam mempengaruhi minat mahasiswa untuk berwirausaha.

Subjek penelitian adalah mahasiswa yang mengikuti perkuliahan kewirausahaan pada tahun ajar 2020/2021 dengan media pembelajaran video dan pesan singkat (WAG) yaitu sejumlah 187 mahasiswa.

$$
n=\frac{N}{N \cdot d^{2}+1}=\frac{187}{\begin{array}{c}
\left(187 \cdot\left(0,05^{2}\right)\right)+1 \\
=127.427
\end{array}}=\frac{187}{(187.0 .0025)+1}
$$

Jumlah sampel ditentukan dengan teknik sampel Yamane dan berdasarkan perhitungan diperoleh sampel penelitian sejumlah 128 mahasiswa.

Instrumen penelitian merupakan kuesioner yang dibagikan 128 mahasiswa yang dipilih secara acak untuk menjadi sampel penelitian dan pengumpulan data menggunakan google form.

Hipotesis yang akan diuji dalam penelitian adalah :

HO : Tidak ada perbedaan minat berwirausaha mahasiswa yang diajarkan dengan video dan aplikasi pesan H1 : Terdapat perbedaan minat berwirausahan mahasiswa yang diajarkan dengan video dan aplikasi pesan

\section{HASIL DAN PEMBAHASAN}

Pembelajaran jarak jauh dalam perkuliahan kewirausahaan sebagai salah satu partisipasi universitas dalam mematuhi protokol kesehatan selama masa pandemi covid-19 dilaksanakan dengan media pembelajaran dan aplikasi-aplikasi yang dapat diakses menggunakan jaringan internet.

Secara umum, tingkat minat berwirausaha mahasiswa berada pada kategori rendah terlihat bahwa sebanyak $60,15 \%$ dari mahasiswa yang menjadi sampel penelitian. Hasil kuesioner menunjukan bahwa minat mahasiswa setelah melaksanakan pembelajaran jarak jauh dengan media video dan aplikasi pesan dapat terlihat pada Tabel 1. Tabel 1. Distribusi Frekuensi Minat Berwirausaha

\begin{tabular}{lccc}
\hline Kategori & Jangkauan & Frekuensi & Presentase \\
\hline Minat Rendah & $10-19$ & 77 & 60,15 \\
\hline Minat Sedang & $20-29$ & 51 & 39,85 \\
\hline Minat Tinggi & $30-40$ & 0 & 0 \\
\hline
\end{tabular}

Sumber: diolah peneliti.2021

Materi kuliah yang mayoritas berupa bahan bacaan tidak bisa dipahami secara menyeluruh oleh mahasiswa sehingga mahasiswa kesulitan dalam memahami materi kuliah yang diberikan secara terbatas pada video dan aplikasi pesan instan. Terlihat bahwa mambaca materi dan mengerjakan tugas terasa tidak cukup menimbulkan minat mahasiswa untuk berwirausaha, mereka membutuhkan penjelasan secara verbal dan langsung dari dosen mengenai beberapa materi yang sifatnya motivasi atau kasus. Komunikasi dengan dosen melalui applikasi pesan instan ataupun penjelasan pada video tidak mampu menyediakan informasi yang menyeluruh mengenai materi tentang kewirausahaan.

\section{Uji Hipotesis}

Penelitian dilakukan dengan metode t-test, namun terlebih dahulu data perlu dinyatakan berdistribusi normal dan homogen sehingga dilakukan uji normalitas dengan Shapiro-Wilk dan uji homogenitas dengan Levene's Test.

Hasil uji (tabel 2) menunjukan bahwa data pada kelompok mahasiswa yang menerima materi dengan video memiliki nilai sig 0,711>0,05 yang berarti data pada kelompok tersebut berdistribusi normal. Kelompok mahasiswa yang menerima pembelajaran dengan media aplikasi pesan instan (WAG) memiliki nilai sig 0,204 > 0,05 yang berarti data pada kelompok WAG berdistribusi normal. Homogen dengan uji Levene's menghasilkan nilai sig 0,341 > 0,05 yang berarti data bersifat homogen, hal ini menjadi landasan sehingga data bisa dilanjutkan dengan pengujian hipotesis.

Tabel 2. Hasil Uji Normalitas dan Homogenitas

\begin{tabular}{lll}
\hline Shapiro-Wilk & Video & .711 \\
\cline { 2 - 3 } & WAG & .204 \\
\hline Levene's Test for Equality of Variances & .341 \\
\hline
\end{tabular}

Uji Hipotesis dengan t-test akan menjawab hipotesis yang diajukan yaitu :

H0 : Tidak ada perbedaan minat berwirausaha mahasiswa yang diajarkan dengan video dan aplikasi pesan

H1 : Terdapat perbedaan minat berwirausahan mahasiswa yang diajarkan dengan video dan aplikasi pesan

Hasil uji menunjukan nilai sig adalah 0,817>0,05 sehingga H0 diterima yang berarti tidak ada perbedaan minat kewirausahaan yang diajarkan dengan video dan aplikasi pesan.

Tabel 3. Hasil Uji t-test

\begin{tabular}{clccc}
\hline & & \multicolumn{3}{c}{ t-test for Equality of Means } \\
\cline { 3 - 5 } Minat_Kwu & $\begin{array}{l}\text { Equal variances } \\
\text { assumed }\end{array}$ & .232 & 126 & Sig. (2-tailed) \\
\cline { 2 - 5 } & $\begin{array}{l}\text { Equal variances } \\
\text { not assumed }\end{array}$ & .232 & 125.072 & .817 \\
\hline
\end{tabular}

Penelitian ini dapat dikatakan sejalan dengan hasil penelitian Garrison \& Cleveland-Innes (2005) yang merekayasa keterlibatan dosen dalam perkuliahan secara online, dimana keterlibatan dosennya sangat sedikit sehingga tidak menunjukkan adanya pembelajaran yang mendalam dan bermakna. Pembelajaran jarak jauh bukanlah hal yang baru dalam dunia pendidikan namun ketika dalam persiapan dan pelaksanaannya dilakukan secara terburu-buru dan mendadak maka hasil yang diperoleh kurang maksimal. 
Hoskins (2013) menyimpulkan bahwa tidak mudahnya melakukan pembelajaran jarak jauh dikalangan mahasiswa karena perlu memperhatikan desain kelas dan metode penyampaian yang tepat sehingga tujuan pembelajaran tercapai, perlunya mendorong mahasiswa untuk 1) merefleksikan kepercayaan mereka; 2)menyediakan lingkungan untuk berdiskusi; 3)membimbing mereka untuk mengeksplorasi, 4)memvalidasi dan memperluas pandangan baru serta 5)mendukung untuk pengembangan peran baru mereka.

Pelaksanaan pembelajaran kewirausahaan sebelum masa pandemi memungkinkan dosen untuk menggunakan bermacam-macam metode dan media pembelajaran ketika tatap muka, seperti pembelajaran kewirausahaan berbasis proyek yang mampu menumbuhkan minat wirausaha dengan sangat baik (Farida.2017)

Namun dengan perubahan yang mendadak dimana dosen harus merubah media dan metode dalam proses belajar mengajar tanpa adanya persiapan maka hasilnya terlihat bahwa minat mahasiswa untuk berwirausaha berada pada kategori rendah, hal ini sejalan dengan hasil yang ditemukan Hidayat (2018) bahwa pembelajaran kewirausahaan penting dilakukan secara langsung, mengingat karakteristik materi yang disampaikan berbasis produktif.

Pembelajaran jarak jauh memerlukan lebih banyak interaksi antara mahasiswa dengan dosen karena akan mempengaruhi jarak psikologis yang pada gilirannya akan menuntun pada pembelajaran yang lebih baik (Swan, 2002). Mahasiswa dan dosen yang tidak berada pada satu lokasi atau terpisah selama pembelajaran, akan meminimalisir kemungkinan terjadinya kontak fisik sehingga pada gilirannya mampu mendorong munculnya perilaku social distancing namun mengurangi kedekatan emosional dalam proses pembelajaran.

Media Video yang berbentuk audio visual dan digunakan untuk menyampaikan materi pelajaran membantu untuk memperjelas dan mempermudah penyampaian pesan, mengatasi keterbatasan waktu, ruang, dan indera peserta didik dan dapat digunakan sebagai variasi media pembelajaran namun tidak menyediakan jawaban secara langsung bagi mahasiswa yang memiliki rasa ingin tahu disaat pembelajaran berlangsung, terdapat perbedaan waktu untuk mahasiswa tersebut mendapatkan jawaban atas rasa keingintahuannya.

Pengetahuan dan informasi mengenai wirausaha akan berlanjut pada partisipasi mahasiswa guna mendapatkan pengalaman yang pada akhirnya memunculkan keinginan untuk melakukan kegiatan wirausaha tersebut. Saat keingintahuan mahasiswa terhambat oleh keterbatasan waktu dan jarak maka akan mempengaruhi minat terhadap pengetahuan yang sedang dipelajari.
Selain kondisi dunia pendidikan yang mengalami "syok" akibat pandemi, fakta lain yang terjadi dimasyarakat adalah berkurangnya lapangan kerja karena beberapa alasan yaitu perusahaan yang harus mengurangi tenaga kerja bahkan menutup operasionalnya karena permintaan produk hasil perusahaan yang berkurang dan daya beli masyarakat turun, kondisi ini merupakan kenyataan yang turut mempengaruhi rendahnya minat mahasiswa untuk mencoba menjadi wirausaha.

\section{SIMPULAN}

Penerapan pembelajaran jarak jauh memungkinkan mahasiswa untuk mengikuti perkuliahan dari rumah masing-masing. Mereka dapat mengakses bahan ajar dan mengirimkan tugas yang diberikan oleh dosen tanpa harus datang ke kampus, hal ini dapat mengurangi potensi munculnya kerumunan dilingkungan universitas.

Pembelajaran jarak jauh yang dilakukan secara mendadak guna mengikuti protokol kesehatan dimasa pandemi terlihat belum menunjukan hasil yang maksimal, terlihat dari minat berwirausaha yang rendah, dan penggunaan media video dan pesan instan ternyata tidak memiliki perbedaan dalam mempengaruhi minat mahasiswa untuk berwirausaha.

Pemilihan media yang sesuai dengan karakteristik materi dan matakuliah dalam pembelajaran jarak jauh sangat penting sehingga perlu dilakukan pendekatan media pembelajaran diluar video dan pesan instan, beberapa media pembelajaran yang bisa dipertimbangkan antara lain video conference dan kelas-kelas virtual. Selain media pembelajaran, para dosen mungkin bisa merencanakan metode-metode belajar mengajar yang sesuai dengan keterbatasan jarak

\section{DAFTAR PUSTAKA}

Buchari Alma. (2013). Kewirausahaan. Bandung: Alfa Beta.

Chan, N. N., Walker, C., \& Gleaves, A. (2015). An exploration of students' lived experiences of using smartphones in diverse learning contexts using a hermeneutic phenomenological approach. Computers and Education. https://doi.org/10.1016/j.compedu.2014.11.001

Farida, E dkk. 2017. Pengembangan Model Pembelajaran Kewirausahaan Berbasis Proyek Untuk Menumbuhkan Semangat Wirausaha Mahasiswa Prodi Pendidikan Ekonomi IKIP PGRI Bojonegoro. JPEK Vol 1. Nomor 1 Juli 2017. Hal $8-18$

Firman dan Rahman, S.R. (2020). Pembelajaran Online di Tengah Pandemi Covid-19. Indonesia Journal of Education Science (IJES) Vol. 02 No.02 Maret 2020. 
Garrison, D. R., \& Cleveland-Innes, M. (2005). Facilitating Cognitive Presence in Online Learning : Interaction Is Not Enough. The American Journal of Distance Education. 19(3), 133-148. https://doi.org/10.1207/s15389286ajde1903

Gikas, J., \& Grant, M. M. (2013). Mobile computing devices in higher education: Student perspectives on learning with cellphones, smartphones \& social media. Internet and Higher Education. https://doi.org/10.1016/j.iheduc.2013.06.002

Gökçearslan, Ş., Mumcu, F. K., Haşlaman, T., \& Çevik, Y. D. (2016). Modelling smartphone addiction: The role of smartphone usage, self-regulation, general self-efficacy and cyberloafing in university students. Computers in Human Behavior. https://doi.org/10.1016/j.chb.2016.05.091

Hidayat. H. dkk. 2018. Pembelajaran Kewirausahaan Dengan Pendekatan Berbasis Produksi Sebagai Alternatif Mempersiapkan Lulusan Berkualitas Di Pendidikan Tinggi. Seminar Nasional Pakar ke 1 tahun 2018. Buku 2.

Hoskins. Barbara J. 2013.Is Distance Learning Transformational?.The Journal of Continuing Higher Education,61:1,62- 63,DOI: 10.1080/07377363.2013.759488.B

Iftakhar, S. (2016). Google Classroom: What Works And How? Journal of Education and Social Sciences.

Kay, R. H., \& Lauricella, S. (2011). Exploring the Benefits and Challenges of Using Laptop Computers in Higher Education Classrooms: A Formative Analysis. Canadian Journal of Learning and Technology / La Revue Canadienne de l'apprentissage et de La Technologie. https://doi.org/10.21432/t2s598

Korucu, A. T., \& Alkan, A. (2011). Differences between m-learning (mobile learning) and e- learning, basic terminology and usage of m-learning in education. Procedia - Social and Behavioral Sciences.

https://doi.org/10.1016/j.sbspro.2011.04.029

Kuo, Y. C., Walker, A. E., Schroder, K. E. E., \& Belland, B. R. (2014). Interaction, Internet self-efficacy, and self-regulated learning as predictors of student satisfaction in online education courses. Internet and Higher Education. https://doi.org/10.1016/j.iheduc.2013.10.001

Munir. 2009. Pembelajaran Jarak Jauh Berbasis Teknologi Informasi Dan Komunikasi. Bandung: Alfabeta.

So, S. (2016). Mobile instant messaging support for teaching and learning in higher education. Internet and Higher Education. https://doi.org/10.1016/j.iheduc.2016.06.001

Stein, R. (2020). COVID-19 and Rationally Layered Social Distancing . International Journal of Clinical Practice.
Sun, P. C., Tsai, R. J., Finger, G., Chen, Y. Y., \& Yeh, D. (2008). What drives a successful e- Learning? An empirical investigation of the critical factors influencing learner satisfaction. Computers and Education. https://doi.org/10.1016/j.compedu.2006.11.007 https://doi.org/10.1111/ijcp.13501 